\title{
Lectotypification and Synonymy in Hortia (Rutaceae)
}

\author{
Milton Groppo \\ Departamento de Biologia, Faculdade de Filosofia, Ciências e Letras de Ribeirão Preto, \\ Universidade de São Paulo, Av. Bandeirantes 3900, 14040-901, Ribeirão Preto-SP, Brazil. \\ groppo@ffclrp.usp.br
}

José R. Pirani

Instituto de Biociências, Universidade de São Paulo, Caixa Postal 11461, 05422-970, São Paulo, Brazil

AbSTRACT. During taxonomic revision of the genus Hortia Vandelli (Rutaceae), it was necessary to lectotypify the name $H$. megaphylla Taubert because of the destruction of the holotype at B during World War II. This name is also formally synonymized under H. longifolia Spruce ex Engler. The author attribution is changed for $H$. longifolia Spruce ex Engler, crediting Spruce rather than Bentham.

Resumo. Durante a revisão do gênero Hortia Vandelli (Rutaceae), foi verificada a necessidade de lectotipificação do nome $H$. megaphylla Taubert, em razão da destruição do holótipo depositado em B durante a Segunda Guerra Mundial. Esse nome também é formalmente sinonimizado em $H$. longifolia Spruce ex Engler. A atribuição do autor é mudada para H. longifolia Spruce ex Engler, dando crédito a Spruce ao invés de Bentham.

Key words: Brazil, Hortia, Rutaceae.

Hortia Vandelli is a Neotropical genus of Rutaceae, traditionally included in subfamily Toddalioideae, subtribe Toddaliinae (Engler, 1931). The 10 species are distributed from Panama to the state of São Paulo, Brazil, most of them occurring in the Amazonian region. They are trees or shrubs with simple leaves crowded near the apices of the branches, showy broad corymbose terminal inflorescences, reddish to pink flowers, and baccate fruits with abundant oil glands (Groppo et al., 2005).

The revision of the genus is to be accomplished by the authors, and during the process it was necessary to lectotypify the name Hortia megaphylla Taubert. This name is also formally synonymized under $H$. longifolia Spruce ex Engler, a taxon that encompasses individuals with an exclusively Amazonian distribution.

Hortia longifolia Spruce ex Engler, in Martius \& Eichler, Fl. Bras. 12(2): 184. 1874. TYPE: Brazil. "prope Barra, prov. Rio Negro, March-
Aug. 1851," R. Spruce 1484 (holotype, BR; isotypes, BM, C not seen, C photo at F [F 22049], GH [2], IAN, K [3], K photo 2872 [of one K isotype] at MG, MO, NY).

Hortia duckei Huber, Bol. Mus. Paraense Emílio Goeldi 5(2): 424. 1909. TYPE: Brazil. Pará: "in silvis prope Faro, 17 Aug. 1907," A. Ducke s.n. (holotype, MG 8379; isolypes, $\mathrm{G}, \mathrm{G}$ photos as $\mathrm{F} 26425$ at $\mathrm{GH}, \mathrm{IAN}$, INPA 124.64, MO, NY, RB 211775).

Hortia megaphylla Taubert, Bot. Jahrb. 15(2): 6. 1892. Syn. nov. TYPE: Brazil. [Amazonas:] Manaus, Schwacke III.472 (lectotype, designated here, P; duplicates, K, R).

In the description of Hortia megaphylla, Taubert (1892) cited just one collection (Glaziou 13656). He did not cite a specific type locality, only "Brasilia, verisimiliter boreali loco non indicato" (Taubert, 1892: 6) and an observation by Schwacke that the material had been collected perhaps in Amazonia. This observation agrees with the fact that the distribution of $H$. longifolia is exclusively Amazonian.

On a duplicate specimen of Glaziou 13656 at K, however, the locality as "environs of Rio de Janeiro" is signed as the locality of collection. This discrepancy also appears in a specimen deposited at $\mathrm{P}$, which bears two labels (one in ink and another in pencil) on the same sheet; both state that the collection was made from a shrub cultivated at Quinta de São Christóvão, Rio de Janeiro, planted there by Riedel 16 April 1881. "Glaziou (n. 13656)" appears on the label in ink, but not on the one in pencil, where "Schw. III.472" is written (clearly with another pencil) in the bottom right. A specimen at $\mathrm{R}$, collected in Manaus (Brazilian Amazonia) by Schwacke, clearly bears the number III.472. Thus, the collections Schwacke III.472 (from Manaus) and Glaziou 13656 appear to be the same, and the assumption that the type collection of Hortia megaphylla was made from a cultivated plant at Rio de Janeiro is probably erroneous. It is well known that Glaziou labeled collections made by Schwacke in Amazonia as 
collected by himself at Rio de Janeiro (Stafleu \& Cowan, 1976-1988, vol. 5: 415). This appears to be the case with the type collection of H. megaphylla. For details of how Glaziou incorporated specimens collected by Schwacke and Riedel into his own herbarium, see Wurdack (1970).

The specimen at B used by Taubert (1892: 6) to describe Hortia megaphylla ("Glaziou 13656," indeed Schwacke III.472 as explained above) was destroyed during World War II. The duplicate deposited at P is thus chosen as lectotype. In addition to bearing more flowers and buds than the specimens from $\mathrm{K}$ and $\mathrm{R}$ (duplicates of Schwacke III.472), the $\mathrm{P}$ specimen bears the two labels that helped to resolve the confusion about the type collection.

Ducke (1922: 182), when he synonymized Hortia duckei Huber with $H$. longifolia, noted that Huber (1909) had examined only young buds to establish his new species, using the shape of the buds as the main difference between his species and $H$. longifolia (buds ovoid in $H$. longifolia vs. oblong in H. megaphylla). The buds of $H$. longifolia are, indeed, ovoid when young, but they become oblong just before anthesis. In the same work, Ducke commented that a collection made by Ule deposited at MG (Ule 8926, seen) and identified as $H$. megaphylla Taubert in sched. belonged to $H$. longifolia, without, however, printed synonymy of the name. We agree with Ducke, and $H$. megaphylla Taubert is herein formally synonymized with $H$. longifolia, based on our examination of the types of the two names.

On all examined duplicates of Spruce 1484, there are smaller labels naming the species as "Hortia longifolia sp. nov." made by Spruce himself. On the holotype of this species, however, there is another label ("Herbarium Martii") written "Hortia longifolia Bentham, communicatvit Bentham 1857." Nevertheless, neither Spruce nor Bentham validated the name. When Engler (1874) formally described H. longifolia, he attributed the species to Spruce. According to the ICBN, Art. 46.7 (McNeill et al., 2006): "in determining the correct author citation, only internal evidence in the publication...where the name was validly published is to be accepted [underline by the authors], including ascription of the name...." Therefore, $H$. longifolia Spruce ex Engler, not $H$. longifolia Bentham ex Engler, is the correct author attribution.

Acknowledgments. The authors thank the curators of the following herbaria for the loan of specimens or for allowing consultation of the collection: BHCB, BM, BR, CEN, CEPEC, ESA, F, GFJP, GH, GUA, HAMAB, HEPH, HUA, HUEFS, HUFU, HXBH, IAC, IAN, IBGE, ICN, INPA, IPA, K, M, MBM, MBML, MG, MO, NY, OUPR, P, R, RB, RFA, SP, SPF, UB, UEC, VIC, and W; the Fundação Botânica Margaret Mee, for an award granted to the first author; Victoria Noble (BM), Cecile Aupic, and Marc Pignal (P) for their help in consulting the collections; Robert Vogt for checking the B collection; Jacquelyn Kallunki (NY), for her important suggestions and improvements in an earlier version of the text; and to FAPESP (Fundação de Amparo à Pesquisa do Estado de São Paulo, grant no. 00/07401-0) for financial support.

\section{Literature Cited}

Ducke, A. 1922. Plantes nouvelles ou peu connues de la région amazonienne ( $\mathrm{II}^{\mathrm{e}}$ parte). Arch. Jard. Bot. Rio de Janeiro 3: 3-281, t. 1-24.

Engler, H. G. A. 1874. Rutaceae. Pp. 75-196 in C. F. P. de Martius \& A. G. Eichler (editors), Flora Brasiliensis, Vol. 12, Parte 2. Typographia Regia, Monachii.

1931. Rutaceae. Pp. 187-359 in A. Engler \& K. Prantl (editors), Die natürlichen Pflanzenfamilien, Vol. 19a. Ed. 2. Wilhelm Engelmann, Leipzig.

Groppo, M., J. A. Kallunki \& J. R. Pirani. 2005. Synonymy of Hortia arborea with $H$. brasiliana (Rutaceae) and a new species from Brazil. Brittonia 57(1): 28-34.

Huber, J. 1909. Materiaes para a flora amazonica VII. Plantae Duckeanae austro-guyianenses. Bol. Mus. Goeldi Hist. Nat. Ethnogr. 5(2): 294-436.

McNeill, J., F. R. Barrie, H. M. Burdet, V. Demoulin, D. L. Hawksworth, K. Marhold, D. H. Nicolson, J. Prado, J. E. Skog, J. H. Wiersema \& N. J. Turland (editors). 2006. International Code of Botanical Nomenclature (Vienna Code). Regnum Veg. 146.

Stafleu, F. A. \& R. S. Cowan. 1976-1988. Taxonomic Literature, ed. 2. Vols. 1-7. Scheletema \& Holkema, Utrecht/Antwerpen.

Taubert, P. 1892. Plantae Glaziovianae novae vel minus cognitae. Bot. Jahrb. Syst. 15(2) (Beibl. 34): 3-6.

Wurdack, J. 1970. Erroneous data in Glaziou collections of Melastomataceae. Taxon 19: 911-913. 


\section{$2 \mathrm{BHL}$ Biodiversity Heritage Library}

Groppo, Milton. 2008. "Lectotypification and synonymy in Hortia (Rutaceae)." Novon a journal of botanical nomenclature from the Missouri Botanical Garden $18,48-49$.

View This Item Online: https://www.biodiversitylibrary.org/item/55381

Permalink: https://www.biodiversitylibrary.org/partpdf/57962

\section{Holding Institution}

Missouri Botanical Garden, Peter H. Raven Library

\section{Sponsored by}

Missouri Botanical Garden

\section{Copyright \& Reuse}

Copyright Status: In copyright. Digitized with the permission of the rights holder.

License: http://creativecommons.org/licenses/by-nc-sa/3.0/

Rights: https://biodiversitylibrary.org/permissions

This document was created from content at the Biodiversity Heritage Library, the world's largest open access digital library for biodiversity literature and archives. Visit BHL at https://www.biodiversitylibrary.org. 